\title{
Implementation of Full Day School in Basic Schools in Forming Student's Character
}

\author{
Asti Retnosari ${ }^{1}$, Hasan Hariri ${ }^{2}$, Riswanti Rini ${ }^{3}$, Sowiyah ${ }^{4}$ \\ 1,2,3,4Faculty of Teacher Training and Education, Universitas Lampung, Indonesia
}

\begin{abstract}
The importance of implementing full day school in character building in elementary school students makes the writer interested in making a literature review. Character education is important to be developed and internalized immediately, because it has a noble enough purpose for the provision of students' lives so that they are always ready to respond to all the dynamics of life with full responsibility. The research method used is literature study. The purpose of this literature review is to obtain a theoretical basis that can support problem solving regarding the application of full day school in character building for elementary school students. The results of this research shows that full day school gives positive impact for the children's growth especially on establishing the character values since the early stage started from the elementary school.
\end{abstract}

\section{KEYWORDS: Character Building, Education, Fullday School.}

\section{INTRODUCTION}

Education is a necessity that humans absolutely need in everyday life [1]. Education is considered to be a solution in solving all existing problems, both formal and non-formal education, for example formal education such as school [2]. Primary school is one of the educational institutions that prepares superior humans from an early age, because at the age of 6-12 years it is a development of all their potential for children, both emotionally, intellectually, and morally [3]. Primary schools prepare students for the next level, and basic education must make a high contribution to developing basic skills and student talents [4].

In addition, character building efforts are carried out from an early age so that later children can find out which behavior is good and bad so that there is no character value crisis [5]. Character building is carried out by applying Pancasila values in character education, especially including religious values, honesty, tolerance, discipline, hard work, creative, independent, democratic, curiosity, national spirit, love for the country, respect for achievement, communicative, love peace, love reading, care about the environment, care socially, and be responsible [6].

However, one of the problems currently facing the Indonesian nation is the crisis of character values. Crime that is rife in Indonesia is an example that does not reflect the character of the nation [7]. A hope that many parties want for the realization of a generation capable of maintaining the dignity of the Indonesian nation is not in accordance with what is happening today, the behavior of adolescents who are far from social values and norms is increasingly worrying, such as brawls between students [8]. Based on data from the Indonesian Child Protection Commission (KPAI), the number of violences against children in the education sector as of 30 May 2018 was 161 cases, 23 cases of child victims of brawl, 31 cases of child perpetrators of brawl and cases of children victims of violence and bullying 36 cases [9]. According to data from KPAI 2019, the results of monitoring cases of child violations in the education sector increased from January to April [10]. This is due to the absence of teacher control, especially from parents, and due to the large amount of free time after school, and this free time is used for things that are not useful [11].

Full day school comes as one of the best solutions to overcome those problems, improve education quality in Indonesia, and develop students' character [12]. The full day school system is one form of an educational model that is very supportive to develop student character value [13]. Full day schools were established to accommodate various problems that exist in society, which wants their children to get the best education both from academic and non-academic aspects and to provide protection for children from promiscuity [14]. The idea of full day school is very feasible to minimize the negative influence of the home and outside environment [15]. Full day school is a school that in the implementation of learning is carried out for a full day from morning to evening with part of the time spent on lessons with an informal atmosphere, not rigid, fun for students and requires creativity and innovation from the teacher [16]. Schools that implement a full day school, its implementation are very appropriate for the habituation of students 


\section{International Journal of Current Science Research and Review}

ISSN: 2581-8341

Volume 04 Issue 12 December 2021

DOI: 10.47191/ijesrr/V4-i12-11, Impact Factor: 5.825

IJCSRR@ 2021

WWw.ijesrr.org

so that they can carry out character values in all activities at school under school responsibility and supervision [17]. The role of full-day school can cultivate habits in children and can indirectly shape children's character whether it is about discipline, honesty, leadership to deal with the times that continue to develop. These habituation factors need to be applied to students from an early age, and the habituation of these factors should be done continuously [18].

From the explanation of character formation above, we can understand that character education is important to be developed and internalized immediately; because it has a noble purpose for the life of students so that they are always ready to respond to all the dynamics of life with full responsibility. Full day school will be able to bring students to the formation of personality and character, through habituation when students practice the knowledge they have received while remaining under the supervision of teachers. In other words, all educational stakeholders must be involved in developing character education. However, literature on this topic is under-researched, particularly little known about literature review about the topic in the Indonesian context. Therefore, it is necessary to carry literature review about "How is the implementation of full day school in elementary schools in forming student character?"

\section{LITERATUR REVIEW}

\section{Student Character}

According to the Big Indonesian Dictionary (KBBI) character is a character; psychological, moral or character traits that distinguish one person from another. Character person is a person who has personality, behavior, character, or character. Noble character (good character) which is known about goodness (moral knowing) which makes a commitment to (moral feeling), finally really works and (moral behavior) [19]. There are five important values in strengthening the character that is originally from the Pancasila, since Pancasila is a prior to strengthen the movement on the character education [20]. Character-forming values are religious, honest, disciplined, hard work, creative, independent, democratic, curiosity, national spirit, love for the homeland, respect for achievement, friendly/communicative, love peace, love to read, care for the environment, care about social-, and responsibility [21].

Character education is a system of inculcating character values to school members which includes components of knowledge, awareness or willingness, and actions to implement these values, both to God Almighty, oneself, others, the environment, and nationality to become fully human [22].

\section{Full Day School}

A research claims that students will get many benefits academically and socially by the existing of full-day school [23]. Full day school is able to apply the habituation to be a provision for the students' in their life [24]. Full day school is considered as one way that can be applied in the field of education to fix moral problems and children's character [25]. Full Day School, aims to foster morals and form good character in students, not only providing knowledge but also accompanied by character building so that students are accustomed to doing good behaviors in everyday life [26]. Full day school is a school that is designed in such a way as a formal school, also designed to provide certain expectations for parents of students. For example, plus values that have not been given during formal lessons, include group study exercises, congregational practice of obligatory prayer, practice of reading prayers together and others [27].

\section{RESEARCH METHOD}

The research method that will be used is a literature review. A literature review contains a description of the theory, findings and other research materials obtained from reference materials to formulate a clear frame of mind for the formulation of the problem to be studied. The review process begins by searching for articles on Google scholar, to search for articles with keywords: "Full Day School in character building". The searches ranged from articles published in 2013-2020. The criteria for articles that can be used as literature in this study are:

a. Qualitative and quantitative results from "Full Day School".

b. Research articles written in Indonesian and English.

c. Dissertations and theses are excluded.

The steps in the Literature Review of each variable in "Full Day School" are: 


\section{International Journal of Current Science Research and Review}

ISSN: 2581-8341

Volume 04 Issue 12 December 2021

DOI: 10.47191/ijesrr/V4-i12-11, Impact Factor: 5.825

IJCSRR@ 2021

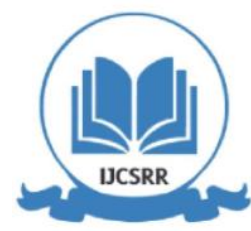

www.ijesrr.org

The first step is to select an appropriate and interesting topic, the issues raised must be written completely and accurately. Then, the literature sought must be relevant to research, so it helps to get an overview of a research topic. Research sources will be very helpful if it is supported by knowledge of the topic to be studied, sources will provide various kinds of descriptions about summaries of several previous studies. After obtaining the literature, pay attention to the contributions made by articles to the topic, the data can be quantitative data, qualitative data or a combination of both. The final step is to analyse and discuss the existing literature as listed in Table 1.

Table 1. List of the literature

\begin{tabular}{|c|c|c|c|}
\hline \multicolumn{4}{|c|}{ Literature Review Study Summaries } \\
\hline Author/ (year) & Title & Method & Results \\
\hline $\begin{array}{l}\text { E. } \\
\text { Wulandari, M. } \\
\text { Taufik, and K. } \\
\text { Kuncahyono } \\
\text { / } 2018\end{array}$ & $\begin{array}{l}\text { Analysis of full } \\
\text { day school } \\
\text { implementation as } \\
\text { an effort for } \\
\text { character building } \\
\text { students at SD } \\
\text { Muhammadiyah } 4 \\
\text { Malang City }\end{array}$ & qualitative & $\begin{array}{l}\text { The process of character building in students is carried out through } \\
\text { school cultural activities, namely routine activities, spontaneous } \\
\text { activities and using character building methods. } \\
\text { The school's solution in overcoming the obstacles to implementing } \\
\text { FDS in the formation of student character is that the school seeks to } \\
\text { provide guidance to all school members both to teachers and } \\
\text { students, establish relationships and collaborate with parents. }\end{array}$ \\
\hline S. Halimah / 2019 & $\begin{array}{l}\text { Building students' } \\
\text { spiritual } \\
\text { intelligence } \\
\text { through the full } \\
\text { day school system } \\
\text { at SDIT Bina } \\
\text { Insan Cendekia } \\
\text { Pasuruan }\end{array}$ & qualitative & $\begin{array}{l}\text { The students' spiritual intelligence is formed and improved through } \\
\text { the full day school system at the Integrated Islamic Elementary } \\
\text { School of BIC Pasuruan. Through habituation then the process of } \\
\text { character formation, character and cultivation of Islamic teachings } \\
\text { can build and improve students' spiritual intelligence. With the } \\
\text { implementation of such systems can improve student achievement, } \\
\text { move the hearts, minds and morals of students. }\end{array}$ \\
\hline $\begin{array}{l}\text { A. Benawa, } \\
\text { R. Peter, and S. } \\
\text { Makmun / } \\
2018\end{array}$ & $\begin{array}{l}\text { The effectiveness } \\
\text { of full day school } \\
\text { system for } \\
\text { students' character } \\
\text { building }\end{array}$ & $\begin{array}{l}\text { qualitativebased } \\
\text { research } \\
\text { method }\end{array}$ & $\begin{array}{l}\text { The full day school system is significantly effective in the education } \\
\text { system for elementary students' character building. The full day } \\
\text { school system embraced the entire relevant processes based on the } \\
\text { character building standard. }\end{array}$ \\
\hline $\begin{array}{l}\text { W. Iskandar and } \\
\text { S. Narimo / } \\
2018\end{array}$ & $\begin{array}{l}\text { Management of } \\
\text { full day school in } \\
\text { shaping the } \\
\text { character of } \\
\text { elementary school } \\
\text { students }\end{array}$ & $\begin{array}{l}\text { qualitative with } \\
\text { ethnography } \\
\text { design }\end{array}$ & $\begin{array}{l}\text { FDS planning begins with the preparation of an academic calendar } \\
\text { so that the learning time received by students can be accepted in full; } \\
\text { environmental conditioning, infrastructure, and school facilities } \\
\text { become media in order to shape the character of students. } \\
\text { The implementation of full day school in shaping the character of } \\
\text { students consists of the cooperation of all teachers and education } \\
\text { staff. }\end{array}$ \\
\hline $\begin{array}{l}\text { J. P. } \\
\text { Triyana, E. T. } \\
\text { Djatmikaand B. } \\
\text { B. } \\
\text { Wiyono / } \\
2018\end{array}$ & $\begin{array}{l}\text { Full day school } \\
\text { system } \\
\text { strengthening the } \\
\text { character } \\
\text { elementary school } \\
\text { students }\end{array}$ & $\begin{array}{l}\text { qualitative } \\
\text { descriptive }\end{array}$ & $\begin{array}{l}\text { The idea of developing a full day school system emerged because } \\
\text { the parents of participants were working, the curriculum was in } \\
\text { accordance with government programs; planning with academic } \\
\text { preparation, conditioning the school, developing syllabus and RPP, } \\
\text { and integrating character. } \\
\text { The impact on parents who are helped and the results of the character } \\
\text { of the students, namely religious, disciplined, responsible, }\end{array}$ \\
\hline
\end{tabular}




\section{International Journal of Current Science Research and Review}

ISSN: 2581-8341

Volume 04 Issue 12 December 2021

DOI: 10.47191/ijesrr/V4-i12-11, Impact Factor: 5.825

IJCSRR@ 2021

\begin{tabular}{|c|c|c|c|}
\hline & & & $\begin{array}{l}\text { independent, caring for the environment and caring for socially } \\
\text { achieve positive results. }\end{array}$ \\
\hline $\begin{array}{l}\text { M. Danil / } \\
2018\end{array}$ & $\begin{array}{l}\text { Implementation of } \\
\text { full day school at } \\
\text { Sabbihisma } \\
\text { Padang } \\
\text { Elementary } \\
\text { School }\end{array}$ & $\begin{array}{l}\text { qualitative } \\
\text { descriptive }\end{array}$ & $\begin{array}{l}\text { Able to have a positive influence on children's development, } \\
\text { especially in inculcating character values because it is supported by } \\
\text { various activities and a pleasant, family and independent school } \\
\text { environment so that students don't feel bored and children's playing } \\
\text { time is still supervised by the teacher. }\end{array}$ \\
\hline $\begin{array}{l}\text { A.P. } \\
\text { Cahyaningsi h / } \\
2020\end{array}$ & $\begin{array}{l}\text { Strengthening of } \\
\text { school-based } \\
\text { character } \\
\text { education (case } \\
\text { study of full-day } \\
\text { school at Cemara } \\
\text { Dua Elementary } \\
\text { School, } \\
\text { Surakarta) }\end{array}$ & $\begin{array}{l}\text { qualitative } \\
\text { research }\end{array}$ & $\begin{array}{l}\text { Schools carry out } 5 \text { main character values through school culture and } \\
\text { habituation for students such as lunch, morning greetings, and } \\
\text { congregational prayers. School culture includes ideas, ideas, norms } \\
\text { in the form of vision and mission and programs in schools such as } \\
\text { extracurricular activities, school ambassadors and outing classes that } \\
\text { prioritize religious values, integrity, independence, nationalism, } \\
\text { cooperation. }\end{array}$ \\
\hline $\begin{array}{l}\text { L. Soapatty and } \\
\text { T. Suwanda / } \\
2014\end{array}$ & $\begin{array}{l}\text { The influence of } \\
\text { the full day school } \\
\text { system } \\
\text { academic } \\
\text { achievement of } \\
\text { students at SMP } \\
\text { Jati Agung } \\
\text { Sidoarjo }\end{array}$ & $\begin{array}{l}\text { quantitative } \\
\text { research }\end{array}$ & $\begin{array}{l}\text { There is a significant influence between the implementation of the } \\
\text { Full Day School system on the academic achievement of SMP Jati } \\
\text { Agung Sidoarjo students. } \\
\text { Supporting factors in implementing the Full Day School system are } \\
\text { adequate facilities and infrastructure, support from parents or the } \\
\text { community, teachers or teaching staff. While the inhibiting factor } \\
\text { lies in the limited land that leads to the fulfillment of school facilities } \\
\text { and infrastructure. }\end{array}$ \\
\hline $\begin{array}{l}\text { M. } \\
\text { Hidayanti / } \\
2018\end{array}$ & $\begin{array}{l}\text { Implementing full } \\
\text { day school in } \\
\text { indonesia: } \\
\text { "analysing } \\
\text { impacts on } \\
\text { students, teachers, } \\
\text { and school } \\
\text { stakeholders }\end{array}$ & $\begin{array}{l}\text { descriptive } \\
\text { qualitative }\end{array}$ & $\begin{array}{l}\text { The most impact appearing in applying to full day school in } \\
\text { Indonesia is the social impact on students. }\end{array}$ \\
\hline $\begin{array}{l}\text { R. Taufika } \\
\text { \& M. Halimi } \\
\text { / } 2019\end{array}$ & $\begin{array}{l}\text { Implementation of } \\
\text { educational policy } \\
\text { at the } \\
\text { implementation of } \\
\text { the full day school } \\
\text { in growing the } \\
\text { religious character }\end{array}$ & $\begin{array}{l}\text { descriptive } \\
\text { research with a } \\
\text { qualitative } \\
\text { approach }\end{array}$ & $\begin{array}{l}\text { The application of a full day school system in fostering religious } \\
\text { character students use varied learning strategies, such as fun } \\
\text { methods, good classroom management based on school culture. } \\
\text { Full day school implementation runs smoothly and can be accepted } \\
\text { by students and parents of students well. }\end{array}$ \\
\hline
\end{tabular}




\section{International Journal of Current Science Research and Review}

ISSN: 2581-8341

Volume 04 Issue 12 December 2021

DOI: 10.47191/ijcsrr/V4-i12-11, Impact Factor: 5.825

IJCSRR@ 2021

www.ijcsrr.org

\begin{tabular}{|c|c|c|c|}
\hline M. Astuti / 2013 & $\begin{array}{l}\text { Implementation of } \\
\text { the fullday school } \\
\text { program as an } \\
\text { effort to encourage } \\
\text { social } \\
\text { development of } \\
\text { superior } \\
\text { kindergarten } \\
\text { students Al-Ya'lu } \\
\text { Malang City }\end{array}$ & $\begin{array}{l}\text { qualitative } \\
\text { method }\end{array}$ & $\begin{array}{l}\text { The implementation of the program to encourage the social } \\
\text { development of children at the Full Day school at the Al-Ya'lu } \\
\text { Superior Kindergarten runs effectively and efficiently. } \\
\text { Supporting factors in an effort to encourage the social development } \\
\text { of students include the availability of sufficient funds due to the } \\
\text { support from foundations and guardians of students, the great } \\
\text { enthusiasm of children in welcoming and running school programs. } \\
\text { The inhibiting factor is the lack of trust of parents in schools to be } \\
\text { able to solve the problems that are being faced by children. }\end{array}$ \\
\hline $\begin{array}{l}\text { G. Prasetya, P. } \\
\text { Nitiasih, and L. } \\
\text { Budiarta / } \\
2020\end{array}$ & $\begin{array}{l}\text { The } \\
\text { implementation of } \\
\text { full day school at } \\
\text { senior high school } \\
\text { in Buleleng } \\
\text { Regency year } \\
2019 / 2020\end{array}$ & $\begin{array}{l}\text { qualitative } \\
\text { research data } \\
\text { analysis } \\
\text { method. }\end{array}$ & $\begin{array}{l}\text { The students' and teachers' perception on the implementation of Full } \\
\text { Day School in SMAN } 4 \text { Singaraja and SMAN } 1 \text { Singaraja are } \\
\text { categorized as positive. And the strengths of full day school were } \\
\text { developing teacher's creativity in terms of teaching and developing } \\
\text { students' creativity in terms of affective, cognitive and psychomotor. }\end{array}$ \\
\hline $\begin{array}{l}\text { H. E. Trisnantari, } \\
\text { P. M. Mutohar, } \\
\text { and S. R. } \\
\text { Rindrayani i } \\
\text { / } 2019\end{array}$ & $\begin{array}{l}\text { Management of } \\
\text { character-based } \\
\text { learning quality } \\
\text { improvement with } \\
\text { full day school } \\
\text { system (FDS) }\end{array}$ & $\begin{array}{l}\text { qualitative } \\
\text { approach }\end{array}$ & $\begin{array}{l}\text { Planning for improving the quality of character-based learning is } \\
\text { based on the national curriculum, school curriculum, excellent } \\
\text { school programs, and extracurricular activities with an integrated } \\
\text { curriculum system. } \\
\text { The implementation of improving the quality of character-based } \\
\text { learning is carried out based on a commitment to achieve the school's } \\
\text { vision, mission, and goals with an active learning system, integrating } \\
\text { character values in the learning process. } \\
\text { Evaluation and quality control of character-based learning is carried } \\
\text { out with an authentic assessment system. }\end{array}$ \\
\hline C. Fajriati/ 2019 & $\begin{array}{l}\text { The role of fullday } \\
\text { school in shaping } \\
\text { the character of the } \\
\text { integrated islamic } \\
\text { elementary school } \\
\text { students As-Syifa } \\
\text { Jambi City }\end{array}$ & $\begin{array}{l}\text { descriptive } \\
\text { qualitative }\end{array}$ & $\begin{array}{l}\text { The long-term habituation method applied to children can instill } \\
\text { Islamic character so that morals and morals can be formed because } \\
\text { children are still in the process of imitation. The full day school } \\
\text { learning system does not only burden the child's brain because each } \\
\text { teacher has their own strategy. and learning emphasizes active } \\
\text { learning (active learning), creative (creative learning), effective } \\
\text { (effective learning), and fun (fun learning). }\end{array}$ \\
\hline $\begin{array}{l}\text { M. Nur and } \\
\text { H. Haris / } \\
2018\end{array}$ & $\begin{array}{l}\text { Implementation of } \\
\text { the full day school } \\
\text { system in } \\
\text { character building } \\
\text { students at SMAN } \\
11 \text { Pangkep, } \\
\text { Pangkep Regency }\end{array}$ & $\begin{array}{l}\text { descriptive } \\
\text { qualitative }\end{array}$ & $\begin{array}{l}\text { The process of character building in the full day school system } \\
\text { includes religious character values carried out through the habit of } \\
\text { praying together, habituation to behave politely and politely etc. } \\
\text { Supporting factors, namely: the role of teachers, facilities and } \\
\text { infrastructure, extracurricular activities coaches and appropriate } \\
\text { methods. While the inhibiting factor is the difference in the } \\
\text { characteristics of students who are different because there are still } \\
\text { some students who are still difficult to manage. }\end{array}$ \\
\hline
\end{tabular}




\section{International Journal of Current Science Research and Review}

ISSN: 2581-8341

Volume 04 Issue 12 December 2021

DOI: 10.47191/ijesrr/V4-i12-11, Impact Factor: 5.825

IJCSRR@ 2021

www.ijesrr.org

\begin{tabular}{|c|c|c|c|}
\hline $\begin{array}{l}\text { F. P. K. } \\
\text { Irmawanty, } \\
\text { S. } \\
\text { Wassauha, M. S. } \\
\text { Sumantri, and } \text { A. } \\
\text { Marini / } \\
2020\end{array}$ & $\begin{array}{l}\text { The } \\
\text { implementation of } \\
\text { full-day school to } \\
\text { build character } \\
\text { education }\end{array}$ & $\begin{array}{l}\text { descriptive } \\
\text { qualitative }\end{array}$ & $\begin{array}{l}\text { The goal of character education is achieved as expected; it requires } \\
\text { an institution that is deemed able to implement it effectively. One } \\
\text { institution that is considered effective in the implementation of } \\
\text { character education is school. }\end{array}$ \\
\hline S. Ningsih / 2017 & $\begin{array}{l}\text { The relationship } \\
\text { between the } \\
\text { implementation of } \\
\text { full day school and } \\
\text { boarding school } \\
\text { with character } \\
\text { building in class } \\
\text { XI MAN } \\
1 \text { Surakarta in } \\
2016 / 2017\end{array}$ & quantitative & $\begin{array}{l}\text { There is a positive and significant relationship between the } \\
\text { implementation of full day school and boarding school with } \\
\text { character building in class XI Students of MAN } 1 \text { Surakarta. }\end{array}$ \\
\hline $\begin{array}{l}\text { R. A. Tia, Z. } \\
\text { Z. Zam, and } \\
\text { H. Pasongli / } \\
2019\end{array}$ & 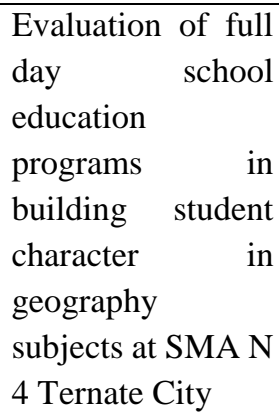 & $\begin{array}{l}\text { evaluative } \\
\text { descriptive }\end{array}$ & $\begin{array}{l}\text { The implementation of the Full Day School education program } \\
\text { policy in the formation of student character in the Geography subject } \\
\text { of SMA Negeri } 4 \text { Ternate City has not been fully formed. }\end{array}$ \\
\hline $\begin{array}{l}\text { D. N. } \\
\text { Pebriany / } \\
2020\end{array}$ & $\begin{array}{l}\text { Analysis } \\
\text { implementation of } \\
\text { full day school in } \\
\text { shaping the } \\
\text { students character } \\
\text { of junior high } \\
\text { school in } \\
\text { Banjarmasin }\end{array}$ & quantitative & $\begin{array}{l}\text { The implementation of full day school in shaping the character of } \\
\text { State Junior High School students in Banjarmasin has been going } \\
\text { well because it has been able to shape the character of students to } \\
\text { live honestly, disciplined, hard work and high social awareness. }\end{array}$ \\
\hline $\begin{array}{l}\text { T. Raharjo, } \\
\text { H. Rohana, } \\
\text { I. Istyarini, } \\
\text { and } \\
\text { Nurussaadah } \\
\text { / } 2018\end{array}$ & $\begin{array}{l}\text { The influence of } \\
\text { full day school on } \\
\text { the formation of } \\
\text { students' religious } \\
\text { character }\end{array}$ & $\begin{array}{l}\text { quantitative } \\
\text { approach }\end{array}$ & $\begin{array}{l}\text { The implementation of full day school has been going well, while } \\
\text { for the religious character of the fifth grade students of SD Nasima } \\
\text { in general it is quite good seen from the independence of students in } \\
\text { carrying out worship. }\end{array}$ \\
\hline
\end{tabular}




\section{International Journal of Current Science Research and Review}

ISSN: 2581-8341

Volume 04 Issue 12 December 2021

DOI: 10.47191/ijcsrr/V4-i12-11, Impact Factor: 5.825

IJCSRR@ 2021

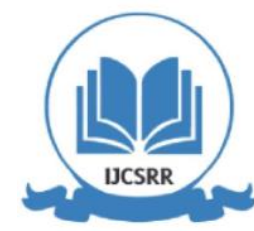

www.ijesrr.org

\begin{tabular}{|l|l|l|l|}
\hline $\begin{array}{l}\text { A. Sarima, J. } \\
\text { Jusma, and } \\
\text { R. Ramlah / } \\
2020\end{array}$ & $\begin{array}{l}\text { Policy analysis of } \\
\text { full day school in } \\
\text { forming student } \\
\text { character }\end{array}$ & $\begin{array}{l}\text { qualitative } \\
\text { method with a } \\
\text { descriptive } \\
\text { approach }\end{array}$ & $\begin{array}{l}\text { The FDS system is oriented to the quality of education and lasts for } \\
\text { a full day using integrated activities that are fun in learning. } \\
\text { Implementation of full day school as an effort to form student } \\
\text { character. The most prominent character values in students are } \\
\text { religious character, independent and caring for the environment, } \\
\text { disciplined character, honest and responsible. }\end{array}$ \\
& $\begin{array}{l}\text { Obstacles to implementing full day school in shaping character are } \\
\text { student awareness, lack of support and appreciation from some } \\
\text { parents or guardians of students, and infrastructure facilities to } \\
\text { support student character formation have not been fulfilled optimally } \\
\text { such as mosques as a means of worship. }\end{array}$ \\
\hline
\end{tabular}

\section{ANALYSIS, RESULTS AND CONCLUSION}

Based on the results of a review of various articles obtained, the results of the analysis show that most of the articles focus on Full Day School and the character of students. Table 1. shows that research related to this topic has been carried out in various educational institutions in Indonesia. The rationale of this article is to find out the implementation of full day school in character building in elementary school students.

The fading of moral values such as lies and the loss of a sense of responsibility, the fading sense of solidarity, and the thinness of the sense of humanity have occurred in Indonesia. The declining character of students such as increasing violence among teenagers, worsening use of language and words in social interactions, waning respect for older people, need further handling in order to create a better generation in the future. Full day school is one solution to overcome educational problems both in academic ability to learn and in moral rights. This is explained by Triyana et al (2018) that the full day school program is an educational solution for students through the active involvement of students in the classroom and the learning process is democratic and fun. The development of this system is a solution for students to avoid negative behavior.

Another finding in this study relates to full day school. The results of research by Fajriati (2019) indicate that the method of continuous habituation in the long term applied to children can instill character so that morals and morals can be formed because children are still in the process of imitation. Sarima et al (2020) stated that with the implementation of full day school, the most prominent characters in students are religious, independent and caring for the environment, disciplined, honest and responsible characters. The research of Irmawanty et al (2018) shows that the goals of character education are achieved as expected; required an institution that is considered capable of implementing it effectively. One of the institutions that are considered effective in the implementation of character education is the school.

The reviews in this literature review have limitations including the articles that are reviewed predominantly from the Indonesian state so that other studies are not reviewed due to limitations, dissertations and theses are excluded in this article and the scope of the articles reviewed is still very limited.

Apart from the limitations of the literature, the findings in this literature review are expected to contribute to the implementation of full day school in character building for elementary students. Based on the findings, it can be concluded that in order to be able to develop children's character from an early age, an institution that is considered effective in implementing character education is needed. The program that can be applied is full day school because it is able to have a positive influence on children's development, especially in instilling character values because it is supported by various activities and a pleasant, family and independent school environment so that students do not feel bored and children's play time remains constant. supervised by the teacher.

\section{REFERENCES}

1. E. Wulandari, M. Taufik, and K. Kuncahyono, "Analysis of full day school implementation as a way of building student character at Muhammadiyah 4 Elementary School Malang City," Jurnal Pemikiran dan Pengembangan Sekolah Dasar (JP2SD), vol. 6, no. 1, pp. 65-74, 2018. 


\section{International Journal of Current Science Research and Review}

ISSN: 2581-8341

Volume 04 Issue 12 December 2021

DOI: 10.47191/ijcsrr/V4-i12-11, Impact Factor: 5.825

IJCSRR@ 2021

Www.ijesrr.org

2. S. Halimah, "Building students' spiritual intelligence through the full day school system at SDIT Bina Insan Cendekia Pasuruan City," Jurnal Al Makrifat Vol, vol. 4, no. 2, 2019.

3. H. A. Hawi, "Full-day school system at integrated islamic elementary school (SDIT) case study in Izzuddin Palembang," Jurnal Istinbath, vol. 15, no. 2, 2015.

4. A. Benawa, R. Peter, and S. Makmun, "The effectiveness of full day school system for students' character building," in IOP Conference Series: Materials Science and Engineering, 2018, vol. 288, no. 1: IOP Publishing, p. 012160.

5. T. H. Yuwono, "Full day school: realization of children's character building," Jurnal Pendidikan Guru, vol. 1, no. 1, pp. 73-83, 2017.

6. W. Iskandar and S. Narimo, "Full day school management in shaping elementary students' character," Manajemen Pendidikan, vol. 13, no. 2, pp. 24-33, 2019.

7. J. P. Triyana, E. T. Djatmika, and B. B. Wiyono, "Full day school system in strengthening the character of elementary school students," Jurnal Pendidikan: Teori, Penelitian, dan Pengembangan, vol. 3, no. 12, pp. 1550-1560, 2018.

8. M. Danil, "Implementation of full day school at SABBIHISMA Padang elementary school," Jurnal Komunikasi Pendidikan, vol. 2, no. 1, pp. 86-92, 2018.

9. A. Pratama, "KPAI records 161 cases of child violence in the education sector during 2018," 23 Juli 2018 . [Online]. Available: https://www.inews.id/news/nasional/kpai-catat-161-kasus-kekerasan-anak-di-bidang-pendidikan-selama-2018.

10. A. P. Cahyaningsih, "Strengthening of school-based character education (case study of full-day school at Cemara Dua Elementary School, Surakarta)," in 3rd International Conference on Learning Innovation and Quality Education (ICLIQE 2019), 2020: Atlantis Press, pp. 620-628.

11. L. Soapatty and T. Suwanda, "The influence of the full day school system on academic achievement of students at SMP Jati Agung Sidoarjo," Kajian Moral dan Kewarganegaraan, vol. 2, no. 2, pp. 717-733, 2014.

12. M. Hidayanti, "Implementing full day school in indonesia:"analysing impacts on students, teachers, and school stakeholders"," International E-Journal of Advances in Education, vol. 4, no. 10, pp. 127-134, 2018.

13. R. Taufika and M. Halimi, "Implementation of educational policy at the implementation of the full day school in growing the religious character," in 2nd Annual Civic Education Conference (ACEC 2019), 2020: Atlantis Press, pp. 279282.

14. M. Astuti, "Implementation of the fullday school program as an effort to encourage the social development of excellent kindergarten students Al-Ya'lu Malang City," Jurnal Kebijakan dan Pengembangan Pendidikan, vol. 1, no. $2,2013$.

15. G. Prasetya, P. Nitiasih, and L. Budiarta, "The implementation of full day school at senior high school in Buleleng Regency Year 2019/2020," Jurnal Pendidikan Bahasa Inggris undiksha, vol. 8, no. 2, pp. 58-64, 2020.

16. A. G. Wicaksono, "The full day school phenomenon in the Indonesian education system," Jurnal Komunikasi Pendidikan, vol. 1, no. 1, pp. 10-18, 2018.

17. H. E. Trisnantari, P. M. Mutohar, and S. R. Rindrayani, "Management of character-based learning quality improvement with full day school system (FDS)," Jurnal Pendidikan Karakter, no. 1, 2019.

18. C. Fajriati, "The role of fullday school in shaping the character of as-syifa integrated islamic elementary school students, Jambi City," JIGC (Journal of Islamic Guidance and Counseling), vol. 3, no. 1, pp. 50-67, 2019.

19. Z. W. Niam, "Fostering children's character through a full day school program based on islamic boarding school values (case study at Madrasah Ibtidaiyah Nurul Ummah Kotagede Yogyakarta)," Belajea; Jurnal Pendidikan Islam, vol. 4, no. 1, pp. 19-34, 2019.

20. A. A. P. Karo-Karo, K. Usman, L. P. Sari, R. Dewi, and B. A. Simangunsong, "result of the formation of student characters in full day school," Jurnal Ilmiah STOK Bina Guna Medan, vol. 8, no. 1, pp. 43-50, 2020.

21. M. Nur and H. Haris, "Implementation of the full day school system in character building students at SMAN 11 Pangkep, Pangkep Regency," Jurnal Tomalebbi, no. 2, pp. 25-33, 2018.

22. F. P. K. Irmawanty, S. Wassauha, M. S. Sumantri, and A. Marini, "The implementation of full-day school to build character education," 2020.

23. A. Sarima, J. Jusma, and R. Ramlah, "Analysis of full day school policy in forming student character," Jurnal Mappesona, vol. 2, no. 1, 2020. 


\section{International Journal of Current Science Research and Review}

ISSN: 2581-8341

Volume 04 Issue 12 December 2021

DOI: 10.47191/ijesrr/V4-i12-11, Impact Factor: 5.825

IJCSRR@ 2021

Www.ijcsrr.org

24. D. N. Pebriany, "Analysis of full day school implementation in character building of state junior high school students in Banjarmasin," Anterior Jurnal, vol. 20, no. 1, pp. 40-45, 2020.

25. T. Raharjo, H. Rohana, I. Istyarini, and N. Nurussaadah, " The effect of full day school on the formation of students' religious character," Indonesian Journal of Curriculum and Educational Technology Studies, vol. 6, no. 1, pp. 22-32, 2018.

26. S. Ningsih, " The relationship between the implementation of full day school and boarding school with character building in class XI MAN 1 Surakarta in 2016/2017," Jurnal Global Citizen: Jurnal Ilmiah Kajian Pendidikan Kewarganegaraan, vol. 2, no. 2, 2017.

27. R. A. Tia, Z. Z. Zam, and H. Pasongli, " Evaluation of the full day school education program in building student character in geography subjects at SMAN 4 Ternate City," Pangea: Wahana Informasi Pengembangan Profesi dan Ilmu Geografi, vol. 1 , no. 02, 2019.

Cite this Article: Asti Retnosari, Hasan Hariri, Riswanti Rini, Sowiyah (2021). Implementation of Full Day School in Basic Schools in Forming Student's Character. International Journal of Current Science Research and Review, 4(12), 1684-1692 